\title{
Could polyhexanide and chlorine dioxide be used as an alternative to chlorhexidine? A systematic review
}

\author{
Dayanne Simões Ferreira Santos', Mariela Peralta-Mamani", Felipe Suaki Brandão'", Flaviana Bombarda Andradelv, \\ Thiago Cruvinel ${ }^{v}$, Paulo Sérgio da Silva Santos ${ }^{\mathrm{v}}$
}

Faculdade de Odontologia de Bauru (FOB), Universidade de São Paulo (USP), São Paulo (SP), Brazil

'DDS. Dentist and Master's Student, Department of Surgery, Stomatology, Pathology and Radiology, Faculdade de Odontologia de Bauru (FOB), Universidade de São Paulo (USP), São Paulo (SP), Brazil.

(D) https://orcid.org/0000-0002-1899-3499

"DDS, MSc. Dentist and Doctoral Student, Department of Surgery, Stomatology, Pathology and Radiology, Faculdade de Odontologia de Bauru (FOB), Universidade de São Paulo (USP), São Paulo (SP), Brazil.

(D) https://orcid.org/0000-0002-0243-9194

"'DDS, MSc. Dentist and Doctoral Student, Department of Dentistry, Dentistry School, Universidade Estadual de Maringá (UEM), Maringá (PR), Brazil.

(D) https://orcid.org/0000-0003-1484-9964

"DDS, PhD. Dentist and Associate Professor, Department of Dentistry, Endodontics and Dental Materials, Faculdade de Odontologia de Bauru (FOB), Universidade de São Paulo (USP), São Paulo (SP), Brazil.

(D) https://orcid.org/0000-0002-1238-2160

vDDS, PhD. Dentist and Associate Professor, Department of Pediatric Dentistry, Orthodontics and Public Health, Faculdade de Odontologia de Bauru (FOB), Universidade de São Paulo (USP),

São Paulo (SP), Brazil.

(D) https://orcid.org/0000-0001-7095-908X

vDDS, PhD. Dentist and Associate Professor, Department of Surgery, Stomatology, Pathology and Radiology, Faculdade de Odontologia de Bauru (FOB), Universidade de São Paulo (USP), São Paulo (SP), Brazil.

(D) https://orcid.org/0000-0002-0674-3759

\section{KEYWORDS (MeSH terms):}

Chlorhexidine.

Polyhexanide [supplementary concept]. Chlorine dioxide [supplementary concept]. Mouthwash.

Systematic review [publication type].

AUTHORS' KEYWORDS:

Oral infection control.

Mouth rinses.

Oral hygiene.

Adverse effects.

Dental management.

\begin{abstract}
BACKGROUND: Maintenance of oral microbiota balance is the simplest way to prevent infectious oral diseases, through controlling dental biofilm. Combined use of mouthwash and mechanical removal has been shown to be a very effective way for this.

OBJECTIVES: To identify clinical studies comparing the antimicrobial effect and possible adverse effects and/or side effects of chlorhexidine-based mouthwashes with those of mouthwashes containing chlorine dioxide and/or polyhexanide, for controlling oral microbiota.

DESIGN AND SETTING: Systematic review designed by the stomatology sector of postgraduation in applied dental sciences of Bauru Dentistry School, University of São Paulo, Brazil.

METHODS: A systematic review was conducted using online databases (PubMed, Embase, Web of Science and Science Direct) up to April 8, 2020. The search was conducted using the Preferred Reporting Items for Systematic Reviews and Meta-Analyses (PRISMA) guidelines.

RESULTS: The studies included comprised eight articles published between 2001 and 2017. A total of 295 young adults, adults and elderly people were evaluated (males $44.75 \%$ and females $55.25 \%$ ). Three articles compared polyhexanide with chlorhexidine and five articles compared chlorine dioxide with chlorhexidine. No studies comparing all three mouthwashes were found. The concentrations of the study solutions were quite varied, and all rinses had an antimicrobial effect. In four studies, it was stated that no side effects or adverse effects had been found. Three studies did not address these results and only one study addressed side effects and/or adverse effects.

CONCLUSION: Mouthwashes containing chlorine dioxide and polyhexanide are viable alternatives to chlorhexidine, since they reduce oral biofilm and have little or no reported side or adverse effects.

SYSTEMATIC REVIEW REGISTRATION: PROSPERO - CRD42019115929 - Available from: https://www.crd. york.ac.uk/prospero/display_record.php?ID=CRD42019115929.
\end{abstract}

\section{INTRODUCTION}

\section{Rationale}

Control of dental biofilm and maintenance of the balance of the oral microbiota is the simplest way to prevent diseases such as periodontal disease and dental caries. ${ }^{1}$ Combined use of mouthwash and mechanical removal has been shown to be a very effective way for controlling cariogenic and periodontogenic biofilms. ${ }^{2}$ These biofilms may present a risk of systemic dissemination through microaspiration or the hematogenous route, with consequent secondary infections.

Among the various chemical agents used to control dental biofilms, chlorhexidine (CHX) is the gold standard because of its excellent bacteriostasis, substantivity, non-specificity and broad spectrum. ${ }^{3,4}$ However, there is evidence that prolonged use of $\mathrm{CHX}$ has adverse effects, such as tooth and restoration staining, mucosal irritation, microbial resistance and changes to taste sensation, thus restricting its use to specific cases in dentistry. ${ }^{3-6}$

Polyhexamethylene biguanide or polyhexanide (PHMB) and chlorine dioxide $\left(\mathrm{ClO}_{2}\right)$ are alternatives to $\mathrm{CHX}$. Studies have demonstrated that $\mathrm{PHMB}$ has a broad antimicrobial spectrum, low risk of contact hypersensitivity and good tolerability by cells and tissues, and that it also promotes wound healing. ${ }^{7.8}$ Interestingly $\mathrm{ClO}_{2}$ is not particularly influenced by variations in mouth $\mathrm{pH}$ after activation. $\mathrm{ClO}_{2}$ has action against bacteria, viruses and fungi and high water solubility that provides it with the ability to penetrate the biofilm quickly to exert its action. ${ }^{9,10}$ To our knowledge, there have not been any clinical or in vitro studies aimed at comparing the effects of these three solutions ( $\mathrm{CHX}, \mathrm{PHMB}$ and $\mathrm{ClO}_{2}$ ). 


\section{OBJECTIVES}

The aim of this systematic review was to identify clinical studies that compared the antimicrobial effect and possible adverse and/or side effects of CHX-based mouthwashes with those of mouthwashes containing $\mathrm{ClO}_{2}$ and/or PHMB, for controlling dental biofilm.

\section{Research question}

Two research questions were formulated:

- Do mouthwashes containing $\mathrm{PHMB}$ and/or $\mathrm{ClO}_{2}$ have antimicrobial efficacy in the oral microbiota comparable to that of $\mathrm{CHX}$ ?

- Do studies with mouthwashes containing $\mathrm{PHMB}$ and/or $\mathrm{ClO}_{2}$ show adverse and/or side effects, in comparison with to the effects associated with CHX?

\section{METHODS}

\section{Study design}

This systematic review was conducted in accordance with the PRISMA guidelines (Preferred Reporting Items of Systematic Reviews and Meta-Analyses). ${ }^{9}$

\section{Participants, interventions and comparators}

All the studies selected met the criteria established through the PICO strategy: (1) Participants: oral microbiota; (2) Intervention: PHMB and/or $\mathrm{ClO}_{2}$; (3) Control: CHX; and (4) Outcomes: antimicrobial efficacy of mouthwashes containing PHMB and/or $\mathrm{ClO}_{2}$, compared with that of $\mathrm{CHX}$.

\section{Systematic review protocol}

The protocol for this systematic review was registered in PROSPERO (CRD42019115929) and is available on the website www.crd.york.ac.uk/PROSPERO/.

\section{Search strategy}

A search of the literature was conducted to survey clinical studies that aimed to investigate the antimicrobial action of mouthwashes containing $\mathrm{PHMB}$ and $\mathrm{ClO}_{2}$, compared with that of $\mathrm{CHX}$. The studies included were identified based on a search strategy for each electronic database: PubMed, EMBASE, Web of Science and Science Direct. The search strategy was designed with Boolean operators (AND/OR) to identify all studies on this topic published in English, Portuguese or Spanish up to December 21, 2020. The descriptors used were "Chlorhexidine", "Polyhexanide", "Dioxide Chlorine" and "Mouthwash". The search strategies are detailed in Table $\mathbf{1 .}$

In the Science Direct database, filters for research articles (31) and conference abstracts (2) were activated in order to exclude texts from encyclopedias, book chapters and other sources.

\section{Eligibility criteria}

This review included clinical studies that evaluated the effectiveness of mouthwashes and studies that compared the action of $\mathrm{PHMB}$ and/or $\mathrm{ClO}_{2}$ in relation to $\mathrm{CHX}$, regardless of the participants' age, sex, systemic changes or medication use.

The following types of studies were excluded: literature review articles, clinical cases or case series, studies that did not evaluate mouthwashes, studies not related to dentistry, in vitro, in situ and animal studies and studies published in other languages.

\section{Data sources, study selection and data extraction}

All records collected were moved to a folder of the reference manager EndNote Web (www.myendnoteweb.com). Any duplication of references was identified and then deleted.

Studies were identified independently by two reviewers (D.S.F.S. and F.S.B.) in two phases: 1. Reading the titles and summaries of each article; and 2. Reading the full text. Any discrepancies during either of these phases were resolved through discussion with a third reviewer (P.S.S.S.).

All studies included were independently examined by two reviewers (D.S.F.S. and F.S.B.) and their main characteristics were extracted in order to perform data synthesis and study quality assessment. Only the information described in the articles was considered.

\section{Data analysis}

A narrative data synthesis was carried out, structured around the characteristics of each study, i.e. the microbiological count, type of microorganism, characteristics of the population, parameters evaluated and results obtained.

\section{Risk of bias}

Two reviewers (D.S.F.S. and F.S.B.) independently assessed the risk of bias in the studies included through using the Cochrane risk of bias tool ( $\operatorname{RoB} 2.0,2008$ ), which is available in the Cochrane manual for developing systematic intervention reviews, version 5.1.0 (Cochrane Handbook, Oxford, United Kingdom, and Melbourne, Australia). ${ }^{10}$ Any discrepancies were resolved by a third reviewer (P.S.S.S.). This tool was chosen to assess the risk of bias in randomized clinical trials ${ }^{10}$ in terms of seven domains: generation of random sequence, allocation concealment, blinding of participants and professionals, blinding of outcome evaluators, incomplete outcomes, selective outcome report and others. These were classified as presenting "low risk", "high risk" or "uncertain risk", in accordance with each criterion of the tool..$^{10}$ Afterwards, the data were inserted into the Review Manager (RevMan Version 5.3, Cochrane Manager Review Center, Oxford, United Kingdom) software, and a riskof-bias graph was generated. 


\section{RESULTS}

\section{Study selection}

A total of 245 studies were initially identified in the following databases: PubMed $(n=132)$, Embase $(n=41)$, Web of Science $(n=39)$ and Science Direct $(n=33)$. Thirty studies were excluded due to duplication. Among the remainder, 48 studies were selected for reading the title and abstract and 39 of these were excluded for the following reasons: they were in vitro or in vivo studies, did not use CHX as a control (comparison), did not use $\mathrm{PHMB}$ and/or $\mathrm{ClO}_{2}$ as an intervention or did not use mouthwashes. Thus, the full texts of nine studies were read. From this, one further study were excluded because it did not meet the eligibility criteria (it was an in vitro and in vivo study about decolonization rates of Staphylococcus aureus). Hence, the final analysis was conducted on eight studies. The detailed sequence can be seen in the study selection flowchart ${ }^{9}$ (Figure 1).

\section{Study characteristics}

Table 1 shows the general characteristics of the studies included, which were published between 2001 and 2017. The search was carried out without restriction on publication date. These studies were conducted in Europe and Asia (Germany, Switzerland, Turkey, India and Indonesia). All of them were randomized clinical studies, and microbiological analyses were performed. ${ }^{8,11-17}$ In total, 295 individuals were evaluated and, in

Table 1. Databases and search strategy

(((("chlorhexidine"[MeSH Terms] OR "chlorhexidine"[All Fields]) AND ("mouthwashes"[Pharmacological Action] OR "mouthwashes"[MeSH Terms] OR "mouthwashes"[All Fields] OR "mouthwash"[All Fields])) OR ("chlorhexidine"[MeSH Terms] OR "chlorhexidine"[All Fields]) OR ("chlorhexidine gluconate"[Supplementary Concept] OR "chlorhexidine gluconate"[All Fields])) AND (phmb[All Fields] OR ("polihexanide"[Supplementary Concept] OR "polihexanide"[All Fields] OR "polyhexamethylene biguanide"[All

Fields]) OR ("polihexanide"[Supplementary Concept] OR "polihexanide"[All Fields] OR "polyhexamethylenbiguanid"[All Fields]) OR ("polihexanide"[Supplementary Concept] OR "polihexanide"[All Fields]) OR (dioxide[All Fields] AND ("chlorine"[MeSH Terms] OR "chlorine"[All Fields])) OR ("chlorine dioxide"[Supplementary Concept] OR "chlorine dioxide"[All Fields])) AND (mouthrinse[All Fields] OR ("mouthwashes"[Pharmacological Action] OR "mouthwashes"[MeSH Terms] OR "mouthwashes"[All

Fields] OR "mouthwash"[All Fields]) OR ("mouthwashes"[Pharmacological Action] OR "mouthwashes"[MeSH Terms] OR "mouthwashes"[All Fields]) OR ("mouthwashes"[Pharmacological Action] OR "mouthwashes"[MeSH Terms] OR "mouthwashes"[All Fields] OR ("mouth"[All Fields] AND "bath"[All Fields]) OR "mouth bath"[All Fields]) OR ("mouthwashes"[Pharmacological Action] OR "mouthwashes"[MeSH Terms] OR "mouthwashes"[All Fields] OR ("mouth"[All Fields] AND"rinse"[All Fields]) OR

PubMed "mouth rinse"[All Fields]) OR ("mouthwashes"[Pharmacological Action] OR "mouthwashes"[MeSH Terms] OR "mouthwashes"[All Fields] OR ("mouth"[All Fields] AND "wash"[All Fields]) OR "mouth wash"[All Fields]) OR ("mouthwashes"[Pharmacological

Action] OR "mouthwashes"[MeSH Terms] OR "mouthwashes"[All Fields] OR ("bath"[All Fields] AND"mouth"[All Fields])) OR ("mouthwashes"[Pharmacological Action] OR "mouthwashes"[MeSH Terms] OR "mouthwashes"[All Fields] OR ("baths"[All Fields] AND "mouth"[All Fields])) OR ("mouthwashes"[Pharmacological Action] OR "mouthwashes"[MeSH Terms] OR "mouthwashes"[All Fields] OR ("mouth"[All Fields] AND "baths"[All Fields]) OR "mouth baths"[All Fields]) OR ("mouthwashes"[Pharmacological Action]

OR "mouthwashes"[MeSH Terms] OR "mouthwashes"[All Fields] OR ("mouth"[All Fields] AND "rinses"[All Fields]) OR "mouth rinses"[All Fields]) OR ("mouthwashes"[Pharmacological Action] OR "mouthwashes"[MeSH Terms] OR "mouthwashes"[All Fields] OR ("rinse"[All Fields] AND "mouth"[All Fields])) OR ("mouthwashes"[Pharmacological Action] OR "mouthwashes"[MeSH Terms] OR "mouthwashes"[All Fields] OR ("rinses"[All Fields] AND "mouth"[All Fields])) OR ("mouthwashes"[Pharmacological Action] OR "mouthwashes"[MeSH Terms] OR "mouthwashes"[All Fields] OR ("wash"[All Fields] AND "mouth"[All Fields]))))

(('chlorhexidine mouthwash'/exp OR 'chlorhexidine mouthwash' OR (('chlorhexidine'/exp OR chlorhexidine) AND ('mouthwash'/ exp OR mouthwash)) OR 'chlorhexidine'/exp OR chlorhexidine OR 'chlorhexidine gluconate'/exp OR 'chlorhexidine gluconate' OR (('chlorhexidine'/exp OR chlorhexidine) AND ('gluconate'/exp OR gluconate))) AND (phmb OR'polyhexamethylene biguanide'/exp OR 'polyhexamethylene biguanide' OR (polyhexamethylene AND ('biguanide'/exp OR biguanide)) OR polyhexamethylenbiguanid OR'polihexanide'/exp OR polihexanide OR'dioxide chlorine' OR (('dioxide'/exp OR dioxide) AND ('chlorine'/exp OR chlorine)) OR 'chlorine dioxide'/exp OR 'chlorine dioxide' OR (('chlorine'/exp OR chlorine) AND ('dioxide'/exp OR dioxide))) AND ('mouthrinse'/

Embase exp OR mouthrinse OR 'mouthwash'/exp OR mouthwash OR'mouthwashes'/exp OR mouthwashes OR'mouth bath' OR (('mouth'/ exp OR mouth) AND ('bath'/exp OR bath)) OR'mouth rinse'/exp OR'mouth rinse' OR (('mouth'/exp OR mouth) AND rinse) OR'mouth wash'/exp OR'mouth wash' OR (('mouth'/exp OR mouth) AND wash) OR 'bath, mouth' OR (bath, AND ('mouth'/exp OR mouth)) OR 'baths, mouth' OR (baths, AND ('mouth'/exp OR mouth)) OR'mouth baths' OR (('mouth'/exp OR mouth) AND ('baths'/exp OR baths)) OR'mouth rinses'/exp OR'mouth rinses' OR (('mouth'/exp OR mouth) AND rinses) OR'rinse, mouth' OR (rinse, AND ('mouth'/exp OR mouth)) OR 'rinses, mouth' OR (rinses, AND ('mouth'/exp OR mouth)) OR 'wash, mouth' OR (wash, AND ('mouth'/exp OR mouth)))) ((((Chlorhexidine mouthwash OR Chlorhexidine) OR Chlorhexidine gluconate) AND (((((phmb OR polyhexamethylene biguanide)

OR polyhexamethylenbiguanide) OR polihexanide) OR dioxide chlorine) OR chlorine dioxide)) AND (()((c(()((mouthrinse OR

Web of Science mouthwash) OR mouthwashes) OR Mouth Bath) OR Mouth Rinse) OR Mouth Wash) OR Bath, Mouth) OR Baths, Mouth) OR Mouth Baths) OR Mouth Rinses) OR Rinse, Mouth) OR Rinses, Mouth) OR Wash, Mouth)). polihexanide OR chlorine dioxide) AND (mouthrinse OR mouthwash OR mouthwashes OR Mouth Bath OR Mouth Rinse OR Mouth Wash) 
the studies in which the participants were separated according to sex, ${ }^{8,11-17} 44.75 \%$ were men and $55.25 \%$ women. Six studies involved young adults with an average age between 18 and 25 years, ${ }^{8,11-13,15,17,18}$ one involved adults and the elderly ${ }^{14}$ with a mean age of $60.8 \pm 15.0$ years and one involved adolescents aged $11-16$ years. $^{16}$

\section{Evaluation profile of the clinical trials}

One study evaluated the antifungal effects of $\mathrm{ClO}_{2}$ compared with those of $\mathrm{CHX} ;{ }^{14}$ one compared $\mathrm{ClO}_{2}$ with $\mathrm{CHX}$, against the chromogenic bacterium species Actinomyces; ${ }^{16}$ three evaluated the effect of PHMB compared with $\mathrm{CHX}$, on oral biofilm; ${ }^{11-13}$ and three compared the effects of $\mathrm{ClO}_{2}$ with those of $\mathrm{CHX}$, on oral biofilm..$^{8,15,17,18}$

One study evaluated totally edentulous individuals and their dentures, ${ }^{14}$ six evaluated the teeth and mucous membranes of young adults, ${ }^{8,11-13,15,17}$ one evaluated the tongue coating, ${ }^{8}$ one evaluated individuals who had undergone orthodontic treatment ${ }^{17}$ and one evaluated molar dental sulcus pigmentation in children. ${ }^{16}$

\section{Mouthwashes}

Three studies compared PHMB with $\mathrm{CHX}^{11-13}$ and the other five compared $\mathrm{ClO}_{2}$ with $\mathrm{CHX} .^{8,14-16,17}$ No studies comparing PHMB with $\mathrm{ClO}_{2}$ or all three solutions simultaneously were found.

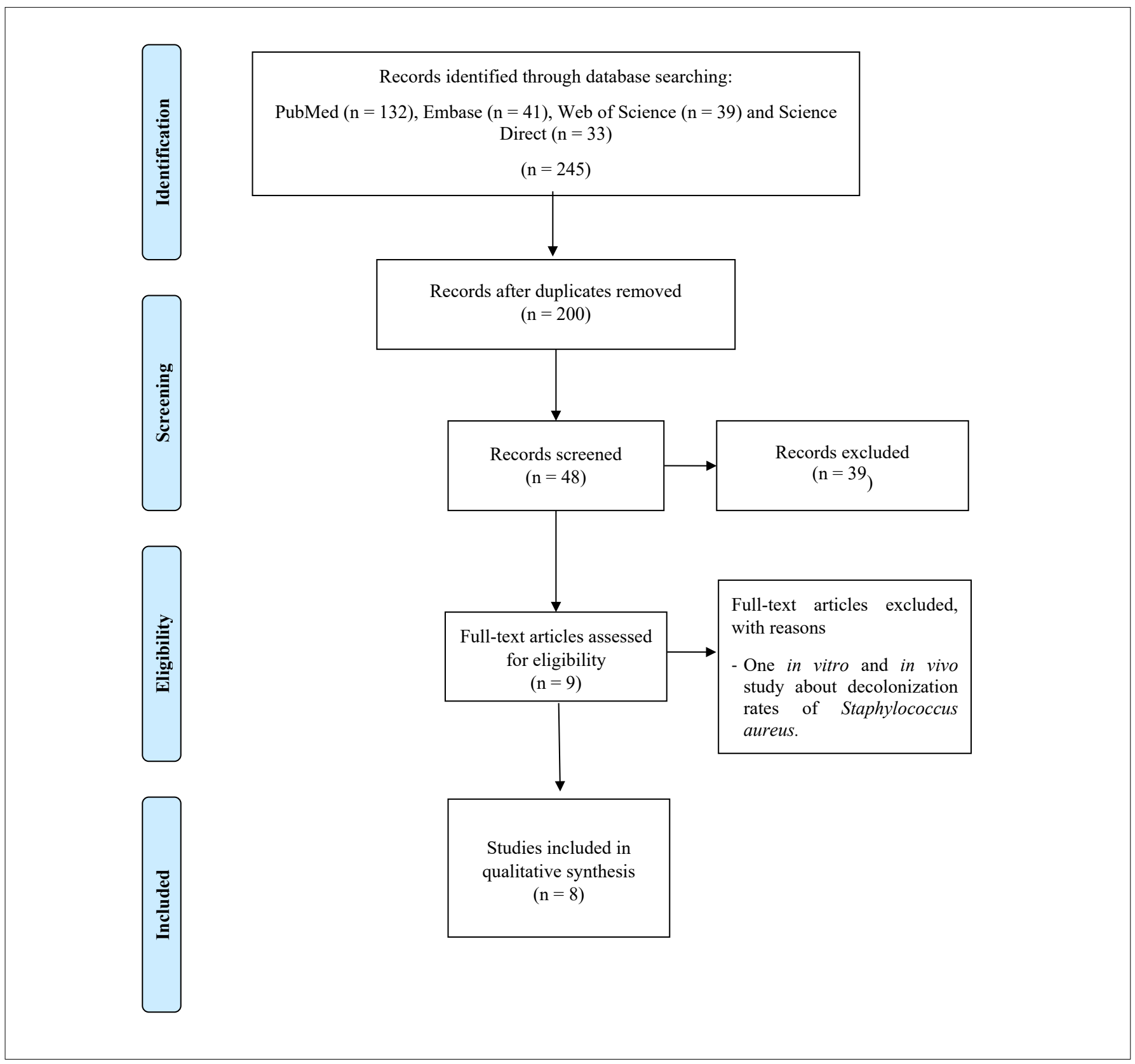

Figure 1. Flow diagram of the studies included for the review. 
The CHX concentration that was most used was $0.20 \%,{ }^{8,14,15}$ followed by $0.12 \%{ }^{11,12}$ and $0.1 \%{ }^{16}$ The PHMB concentrations used were $0.04 \%,{ }^{11} 0.12 \%{ }^{12}$ and $0.20 \%{ }^{13}$ and those of $\mathrm{ClO}_{2}$ were $0.01 \%,{ }^{15} 0.80 \%{ }^{14}$ and $0.1 \% .{ }^{16}$

In all studies, ${ }^{8,11,16,20}$ the frequency of use was two washes per day, i.e. one in the morning and other at night, for each mouthwash. In addition to differences in concentrations, there were differences in quantity, duration of exposure to mouthwash solution and duration of the study (Table 2). The study that evaluated totally edentulous individuals ${ }^{14}$ gave the recommendation that individuals should immerse their dentures in the mouthwash, overnight for 15 days.

\section{Study outcomes}

The primary outcome from this systematic review was to report on the antimicrobial efficacy of mouthwashes containing PHMB and/or $\mathrm{ClO}_{2}$, compared with those containing $\mathrm{CHX}$. The secondary outcome was to report on the adverse effects of mouthwashes.

\section{Antimicrobial efficacy of mouthwashes}

All three studies that compared PHMB with CHX used a concentration of $0.12 \%$ for $\mathrm{CHX}$. These studies evaluated the action of mouthwashes on bacteria. Among their conclusions, one was that the substantivity of CHX was always 12 hours. ${ }^{11-13}$

Regarding the biofilm index, the studies showed that there were significantly lower rates with CHX than with PHMB 0.04\% (P = 0.038). ${ }^{11}$ There were no statistically significant differences between PHMB $0.12 \%$ and CHX (P > 0.05), ${ }^{12}$ and PHMB $0.2 \%$ was significantly less effective on the biofilm index than CHX $(\mathrm{P}=0.016) .{ }^{13}$

The bacterial count was investigated at two times: four hours after using the mouthwash and five days after this. Evaluation of the bacterial count of the dental surface showed that $\mathrm{CHX}$ was significantly more effective in reducing the bacterial count than PHMB 0.04\%, at both times evaluated (four hours, $\mathrm{P}=0.003$; five days, $\mathrm{P}=0.030) .{ }^{11}$ There was no statistically significant difference between PHMB 0.12\% and CHX (P = 0.085) after four hours, while after five days of use, PHMB $0.12 \%$ was significantly less effective than $\mathrm{CHX}(\mathrm{P}=0.008) .{ }^{12}$ In the first four hours, with PHMB 0.20\%, there was no significant difference compared with $\mathrm{CHX}(\mathrm{P}=0.623)$; after five days of use, PHMB $0.2 \%$ significantly inhibited bacterial growth, compared with $\mathrm{CHX}(\mathrm{P}=0.029) .{ }^{13}$

Evaluation of bacterial counts on the mucosal surface showed that $\mathrm{CHX}$ was significantly more effective than PHMB 0.04\% (P = $0.42)^{11}$ and PHMB $0.12 \%(\mathrm{P}=0.013)^{12}$ after the first four hours and after five days of using PHMB $0.04 \%(\mathrm{P}=0.007)^{11}$ and PHMB $0.12 \%(\mathrm{P}=0.000) .{ }^{12}$ There were no significant differences between $\mathrm{PHMB} 0.2 \%$ and $\mathrm{CHX}$ four hours after use $(\mathrm{P}=0.738)$ or five days afterwards: both solutions were equally effective $(\mathrm{P}=1.000) .{ }^{13}$

Other studies compared $\mathrm{ClO}_{2}$ with $\mathrm{CHX}^{8,14-17}$ and found that CHX 0.2\% inhibits biofilm more powerfully than $\mathrm{ClO}_{2} 0.01 \%(\mathrm{P}<$
0.001). ${ }^{15}$ Four hours after use, CHX $0.2 \%$ was found to have been more efficient than $\mathrm{ClO}_{2}$, such that there were fewer colony-forming units (CFUs) on the mucosa $(\mathrm{P}<0.001)$ and on the dental surface $(\mathrm{P}=0.01) .{ }^{8}$ Regarding the biofilm index $(\mathrm{P}=0.05)$, rate of accumulation of tongue biofilm $(\mathrm{P}=0.238)$, presence of bacterial CFUs on the fifth day of mouthwash and application of mouthwashes for 15 days, use of $\mathrm{ClO}_{2}$ was equal to use of $\mathrm{CHX} 0.2 \%(\mathrm{P}=$ 0.160). ${ }^{8}$ It was concluded that the reductions in the dental biofilm index (from 1.30 to $0.84 ; \mathrm{P}<0.01$ ) and gingival index (from 1.43 to $1.23, \mathrm{P}<0.01)$ through use of $\mathrm{ClO}_{2}$ were similar to what was seen regarding the dental biofilm index (from 1.27 to 0.83 ; $\mathrm{P}<0.01$ ) and gingival index (from 1.63 to $1.35 ; \mathrm{P}<0.01$ ) in a mouthwash with $\mathrm{CHX} .{ }^{17}$ In evaluations on fungus, it was concluded that both rinses $\left(\mathrm{ClO}_{2} 0.80 \%\right.$ and $\left.\mathrm{CHX} 0.20 \%\right)$ eliminated Candida albicans hyphae $\left(\mathrm{ClO}_{2}, \mathrm{P}=0.03\right.$; and $\left.\mathrm{CHX}, \mathrm{P}>0.01\right)$, decreased palatal inflammation $\left(\mathrm{ClO}_{2}, \mathrm{P}=0.001\right.$; and $\left.\mathrm{CHX}, \mathrm{P}=0.04\right)$ and eliminated Candida colonization ( $\mathrm{P}=0.001$ for both $).{ }^{14} \mathrm{~A}$ single study showed that $\mathrm{ClO}_{2} 0.1 \%$ had a greater antibacterial effect $(\mathrm{P}=0.001)$ than CHX 0.1\% $(\mathrm{P}=0.01) .{ }^{16}$

\section{Adverse effects/side effects}

The authors of seven studies ${ }^{8,11-14,16,17}$ did not mention the expected adverse or side effects: among these, the authors of four studies reported that they did not observe any adverse effects and/or side effects during their investigations, ${ }^{11-14}$ while such effects were not reported in the results from three studies. ${ }^{8,16,17}$

In one other study, ${ }^{15}$ a questionnaire regarding the perception of mouthwashes was applied. The participants in that study preferred the taste of $\mathrm{ClO}_{2}$ over that of $\mathrm{CHX}(\mathrm{P}<0.001)$ and reported that there was less change in taste when using $\mathrm{ClO}_{2}$ than when using $\mathrm{CHX}(\mathrm{P}<0.001)$. The taste of $\mathrm{CHX}$ remained in the mouth longer than that of $\mathrm{ClO}_{2}(\mathrm{P}<0.001)$, while use of $\mathrm{CHX}$ was more convenient than use of $\mathrm{ClO}_{2}(\mathrm{P}<0.001)$ and the perception of plaque reduction through using $\mathrm{CHX}$ was greater than through using $\mathrm{ClO}_{2}(\mathrm{P}<0.001) .{ }^{15}$

\section{Risk of bias}

In the present study, the Cochrane risk of bias (RoB) tool ${ }^{10}$ was applied to assess the risk of bias in the eight randomized controlled trials that were included. The risk of bias was explored in seven domains.

Two studies were classified as presenting an uncertain risk of bias in three domains, specifically those relating to selection bias (random sequence generation and allocation concealment) and detection bias (blinding of outcome assessment), ${ }^{14,16}$ given that in these studies the randomization and allocation methods were not mentioned and it was not reported whether the results were obtained through blind analysis. Six studies were classified as presenting an uncertain risk of bias in relation to detection bias (blinding 
Table 2. Summary of information contained in the articles included in this review

\begin{tabular}{|c|c|c|c|c|c|c|c|c|}
\hline $\begin{array}{l}\text { Author, } \\
\text { country }\end{array}$ & $\begin{array}{c}\text { Number of } \\
\text { individuals/ } \\
\text { sex/mean age }\end{array}$ & Mouthwash & Concentration & $\begin{array}{l}\text { Quantity } \\
\text { (ml)/ } \\
\text { duration } \\
\text { of } \\
\text { exposure } \\
\text { (s) }\end{array}$ & $\begin{array}{l}\text { Duration } \\
\text { of study } \\
\text { (days) }\end{array}$ & $\begin{array}{c}\text { What was } \\
\text { studied }\end{array}$ & $\begin{array}{l}\text { Microorganism - } \\
\text { Microbiological } \\
\text { count }\end{array}$ & Conclusion \\
\hline
\end{tabular}

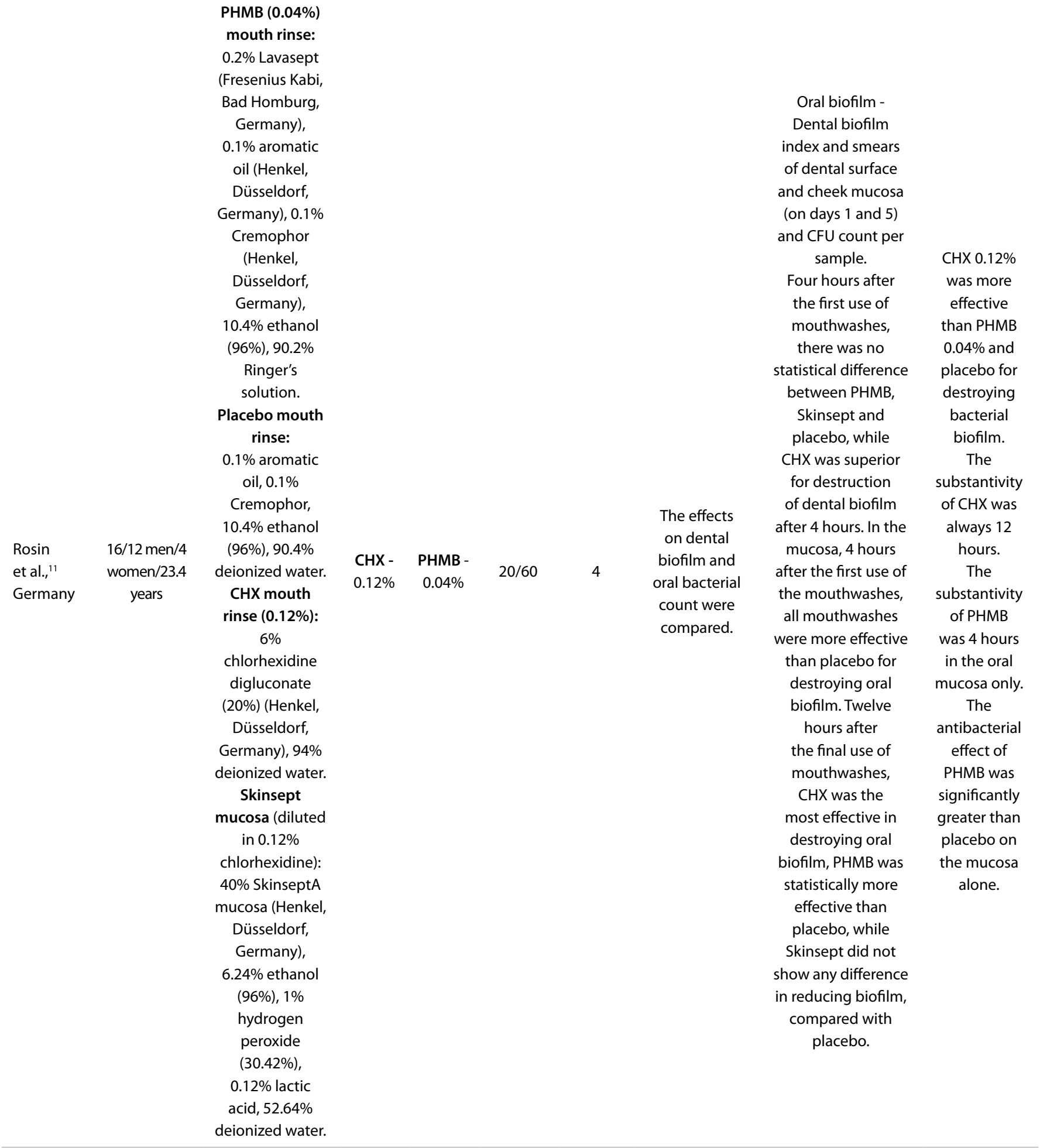


Table 2. Continuation.

\begin{tabular}{|c|c|c|c|c|c|c|c|c|c|}
\hline $\begin{array}{l}\text { Author, } \\
\text { country }\end{array}$ & $\begin{array}{c}\text { Number of } \\
\text { individuals/ } \\
\text { sex/mean age }\end{array}$ & Mouthwash & Conce & tration & $\begin{array}{l}\text { Quantity } \\
\text { (ml)/ } \\
\text { duration } \\
\text { of } \\
\text { exposure } \\
\text { (s) }\end{array}$ & $\begin{array}{c}\text { Duration } \\
\text { of study } \\
\text { (days) }\end{array}$ & $\begin{array}{l}\text { What was } \\
\text { studied }\end{array}$ & $\begin{array}{c}\text { Microorganism - } \\
\text { Microbiological } \\
\text { count }\end{array}$ & Conclusion \\
\hline $\begin{array}{l}\text { Rosin } \\
\text { et al., }{ }^{12} \\
\text { Germany }\end{array}$ & $\begin{array}{c}16 / 6 \text { men/ } \\
10 \text { women/ } \\
23.4 \text { years }\end{array}$ & $\begin{array}{l}\text { PHMB (0.12\%) } \\
\text { mouth rinse: } \\
\text { 0.6\% LavaseptA } \\
\text { (Fresenius Kabi, } \\
\text { Bad Homburg, } \\
\text { Germany), } \\
\text { 0.1\% aromatic } \\
\text { oil (Henkel, } \\
\text { Düsseldorf, } \\
\text { Germany), 0.1\% } \\
\text { Cremophor } \\
\text { (Henkel, } \\
\text { Düsseldorf, } \\
\text { Germany), } \\
\text { 10.4\% ethanol } \\
\text { (96\%), 88.8\% } \\
\text { Ringer's } \\
\text { solution. } \\
\text { Placebo mouth } \\
\text { rinse: } \\
\text { 0.1\% aromatic } \\
\text { oil (Henkel, } \\
\text { Düsseldorf, } \\
\text { Germany), 0.1\% } \\
\text { Cremophor } \\
\text { Froducts, } \\
\text { Geiburg, } \\
\text { (Henkel, } \\
\text { Lamberner- } \\
\text { Consumert, } \\
\text { Düsseldorf, } \\
\text { Germany), } \\
\text { 10.4\% ethanol } \\
\text { (96\%), 89.4\% } \\
\text { deionized water. } \\
\text { CHX mouth } \\
\text { rinse (0.12\%): } \\
\text { 0.6\% } \\
\text { chlorhexidine } \\
\text { digluconate } \\
\text { (20\%) (Henkel, } \\
\text { Düsseldorf, } \\
\text { Germany), 94\% } \\
\text { deionized water. } \\
\text { Essential oil } \\
\text { (Hinse: }\end{array}$ & $\begin{array}{l}\text { CHX - } \\
0.12 \%\end{array}$ & $\begin{array}{c}\text { PHMB - } \\
0.12 \%\end{array}$ & $20 / 60$ & 4 & $\begin{array}{l}\text { To increase } \\
\text { the PHMB } \\
\text { concentration } \\
\text { from } 0.04 \% \\
\text { to } 0.12 \% \text { and } \\
\text { evaluate the } \\
\text { effects on } \\
\text { the biofilm } \\
\text { formed and } \\
\text { oral bacterial } \\
\text { counts, } \\
\text { compared } \\
\text { with CHX } \\
0.12 \% \text {. } \\
\text { To include an } \\
\text { established } \\
\text { commercial } \\
\text { product } \\
\text { (Listerine) } \\
\text { available } \\
\text { for another } \\
\text { comparison. }\end{array}$ & $\begin{array}{l}\text { Oral biofilm - } \\
\text { Dental biofilm } \\
\text { index and smears of } \\
\text { the dental surface } \\
\text { and cheek mucosa } \\
\text { (on days } 1 \text { and 5) } \\
\text { and CFU count per } \\
\text { sample. } \\
\text { Four hours after } \\
\text { the first use of } \\
\text { mouthwashes, no } \\
\text { statistical difference } \\
\text { was observed } \\
\text { between PHMB and } \\
\text { Listerine or PHMB } \\
\text { and CHX regarding } \\
\text { destruction of } \\
\text { dental biofilm; } \\
\text { and } 12 \text { hours after } \\
\text { the final use of } \\
\text { mouthwashes, } \\
\text { PHMB was more } \\
\text { effective for } \\
\text { inhibiting bacterial } \\
\text { growth than } \\
\text { Listerine. In the } \\
\text { mucosa, } 4 \text { hours } \\
\text { after the first use } \\
\text { of mouthwashes, } \\
\text { CHX was the } \\
\text { most effective for } \\
\text { biofiliman placebo } \\
\text { destruction of oral } \\
\text { biofilm. Twelve } \\
\text { hours after the } \\
\text { final use of rinses, } \\
\text { CHX was the most } \\
\text { effective and PHMB } \\
\text { was signicantly } \\
\text { beral }\end{array}$ & $\begin{array}{l}\text { PHMB } \\
\text { mouthwash } \\
\text { showed } \\
\text { significantly } \\
\text { greater } \\
\text { inhibition } \\
\text { of bacterial } \\
\text { biofilm } \\
\text { growth than } \\
\text { placebo. } \\
\text { The bacterial } \\
\text { count } \\
\text { indicated } \\
\text { persistence } \\
\text { of PHMB } \\
\text { antimicrobial } \\
\text { activity } 4 \\
\text { hours after } \\
\text { use. }\end{array}$ \\
\hline
\end{tabular}


Table 2. Continuation.

\begin{tabular}{|c|c|c|c|c|c|c|c|c|c|}
\hline $\begin{array}{l}\text { Author, } \\
\text { country }\end{array}$ & $\begin{array}{c}\text { Number of } \\
\text { individuals/ } \\
\text { sex/mean age }\end{array}$ & Mouthwash & Conce & tration & $\begin{array}{l}\text { Quantity } \\
\text { (ml)/ } \\
\text { duration } \\
\text { of } \\
\text { exposure } \\
\text { (s) }\end{array}$ & $\begin{array}{c}\text { Duration } \\
\text { of study } \\
\text { (days) }\end{array}$ & $\begin{array}{l}\text { What was } \\
\text { studied }\end{array}$ & $\begin{array}{c}\text { Microorganism - } \\
\text { Microbiological } \\
\text { count }\end{array}$ & Conclusion \\
\hline $\begin{array}{l}\text { Welk } \\
\text { et al., }{ }^{13} \\
\text { Germany }\end{array}$ & $\begin{array}{c}\text { 16/ } 6 \text { men/ } 10 \\
\text { women/ } 21.1 \\
\text { years }\end{array}$ & 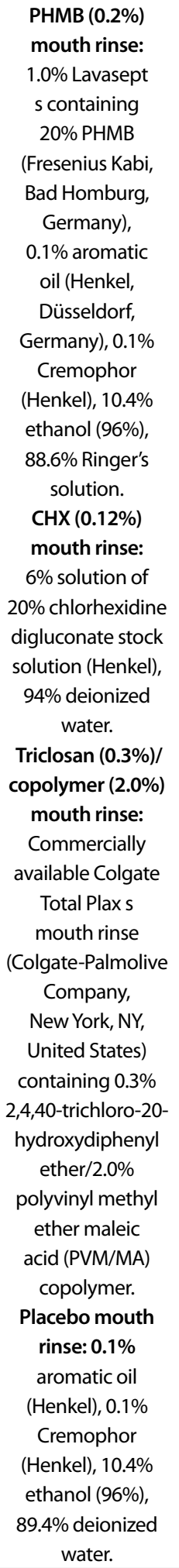 & $\begin{array}{l}\text { CHX - } \\
0.12 \%\end{array}$ & $\begin{array}{c}\text { PHMB - } \\
0.20 \%\end{array}$ & $20 / 60$ & 5 & $\begin{array}{c}\text { Comparison } \\
\text { of mouthwash } \\
\text { containing } \\
\text { PHMB } \\
(0.2 \%) \text { with } \\
\text { mouthwash } \\
\text { containing } \\
\text { CHX (0.12\%), } \\
\text { to evaluate } \\
\text { its effect on } \\
\text { the growth of } \\
\text { dental biofilm } \\
\text { and on oral } \\
\text { bacterial count. }\end{array}$ & $\begin{array}{l}\text { Oral biofilm - Quigley } \\
\text { \& Hein }{ }^{18} \text { dental } \\
\text { biofilm index (QHI), } \\
\text { as modified by } \\
\text { Turesky et al. }{ }^{19} \\
\text { After the first use } \\
\text { of mouthwashes, it } \\
\text { was observed that } \\
\text { CHX was statistically } \\
\text { more effective in } \\
\text { destroying dental } \\
\text { biofilm than other } \\
\text { mouthwashes and } 8 \\
\text { hours after the final } \\
\text { use of mouthwashes, } \\
\text { PHMB inhibited } \\
\text { bacterial growth } \\
\text { more effectively } \\
\text { compared with } \\
\text { triclosan and } \\
\text { placebo. In the } \\
\text { mucosa, after the first } \\
\text { use of mouthwashes, } \\
\text { all mouthwashes } \\
\text { were more effective } \\
\text { than placebo in } \\
\text { destroying oral } \\
\text { biofilm, but there } \\
\text { was no statistical } \\
\text { difference between } \\
\text { them. Eight hours } \\
\text { after the final use } \\
\text { of rinses, PHMB was } \\
\text { equally effective } \\
\text { in destroying oral } \\
\text { biofilm, compared } \\
\text { with CHX. }\end{array}$ & $\begin{array}{c}\text { Dith } \\
\text { The } \\
\text { mouthwash } \\
\text { with } 2.0 \% \\
\text { PHMB was } \\
\text { significantly } \\
\text { less effective } \\
\text { in destroying } \\
\text { bacterial } \\
\text { biofilm } \\
\text { than } 0.12 \% \\
\text { aqueous CHX. } \\
\text { After } 8 \\
\text { hours of } \\
\text { using PHMB, } \\
\text { inhibition } \\
\text { of bacterial } \\
\text { growth was } \\
\text { still observed. }\end{array}$ \\
\hline
\end{tabular}


Table 2. Continuation.

\begin{tabular}{|c|c|c|c|c|c|c|c|c|c|}
\hline $\begin{array}{l}\text { Author, } \\
\text { country }\end{array}$ & $\begin{array}{c}\text { Number of } \\
\text { individuals/ } \\
\text { sex/mean age }\end{array}$ & Mouthwash & \multicolumn{2}{|c|}{ Concentration } & $\begin{array}{l}\text { Quantity } \\
\text { (ml)/ } \\
\text { duration } \\
\text { of } \\
\text { exposure } \\
\text { (s) }\end{array}$ & $\begin{array}{c}\text { Duration } \\
\text { of study } \\
\text { (days) }\end{array}$ & $\begin{array}{l}\text { What was } \\
\text { studied }\end{array}$ & $\begin{array}{l}\text { Microorganism - } \\
\text { Microbiological } \\
\text { count }\end{array}$ & Conclusion \\
\hline $\begin{array}{l}\text { Paraskevas } \\
\text { et al., }{ }^{15} \\
\text { Switzerland }\end{array}$ & $\begin{array}{c}77 / 34 \text { men/ } \\
43 \text { women/ } \\
23.2 \text { years }\end{array}$ & $\begin{array}{l}10 \text { Quist-forte } \\
\text { (containing } 100- \\
\text { ppm free } \mathrm{ClO}_{2} \text { ): } \\
\text { The rinse was } \\
\text { activated when } 5 \\
\text { ml base solution } \\
\text { was mixed with } \\
5 \text { ml activator } \\
\text { solution. De Witte } \\
\text { Tanden Winkel, } \\
\text { Rotterdam, } \\
\text { Netherlands. } \\
\text { Corsodyl } \\
\text { (containing } 0.20 \% \\
\text { CHX, digluconate, } \\
\text { ethanol, polyoxyl } \\
\text { hydrogenated } \\
\text { castor oil, } \\
\text { sorbitol, E-125, } \\
\text { purified water), } \\
\text { GlaxoSmithKline, } \\
\text { Zeist, Netherlands. }\end{array}$ & $\begin{array}{l}\text { CHX - } \\
0.20 \%\end{array}$ & $\begin{array}{l}\mathrm{ClO}_{2}^{-} \\
0.01 \%\end{array}$ & $10 / 60$ & 3 & $\begin{array}{l}\text { To evaluate } \\
\text { inhibition of } \\
\text { growth of } \\
\text { dental biofilm } \\
\text { through use } \\
\text { of mouthwash } \\
\text { containing } \mathrm{ClO}_{2^{\prime}} \\
\text { compared with } \\
\text { mouthwash } \\
\text { with CHX, over } \\
\text { the course of } \\
\text { a 3-day dental } \\
\text { biofilm growth } \\
\text { model. }\end{array}$ & $\begin{array}{l}\text { Dental biofilm - } \\
\text { Dental biofilm index } \\
\text { - In the control group } \\
(\mathrm{CHX}) \text {, the overall } \\
\text { average dental } \\
\text { biofilm index was } \\
1.39 \text {, compared with } \\
1.96 \text { in the test group } \\
\left(\mathrm{ClO}_{2}\right),(\mathrm{P}<0.001) .\end{array}$ & $\begin{array}{l}\text { The } \mathrm{ClO}_{2} \\
\text { rinse was a } \\
\text { less potent } \\
\text { bacterial } \\
\text { biofilm } \\
\text { inhibitor than } \\
\text { the } \mathrm{CHX} \text { rinse. }\end{array}$ \\
\hline $\begin{array}{l}\text { Uludamar } \\
\text { et al., }{ }^{14} \\
\text { Turkey }\end{array}$ & $\begin{array}{c}60 / 23 \text { men/ } \\
37 \text { women/ } \\
60.8 \pm 15 \\
\text { years }\end{array}$ & $\begin{array}{c}\text { Tissue conditioner } \\
\text { material } \\
\text { Visco-gel, } \\
\text { Dentsply Detrey } \\
\text { GmbH, Detrey- } \\
\text { straße 1, D-78467 } \\
\text { Konstanz, } \\
\text { Germany } \\
\text { ClO }_{2}(0.8 \%) \\
\text { dioxidant, } \\
\text { Frontier } \\
\text { Pharmaceutical, } \\
\text { Inc., Melville, NY, } \\
\text { United States). } \\
\text { Corsodyl (0.2\% } \\
\text { CHX gluconate), } \\
\text { Group } \\
\text { Laboratories SA } \\
\text { (Pty) Ltd., Epping } \\
\text { Industrial 1, Cape } \\
\text { Town, South } \\
\text { Africa. }\end{array}$ & $\begin{array}{l}\text { CHX - } \\
0.20 \%\end{array}$ & $\begin{array}{l}\mathrm{ClO}_{2}^{-} \\
0.80 \%\end{array}$ & $30 / 60$ & 15 & $\begin{array}{l}\text { The effect } \\
\text { of tissue } \\
\text { conditioning } \\
\text { and two } \\
\text { mouthwashes } \\
\text { on resolution } \\
\text { of clinical } \\
\text { symptoms } \\
\text { of prosthetic } \\
\text { stomatitis and } \\
\text { on reduction of } \\
\text { Candida } \\
\text { albicans. }\end{array}$ & 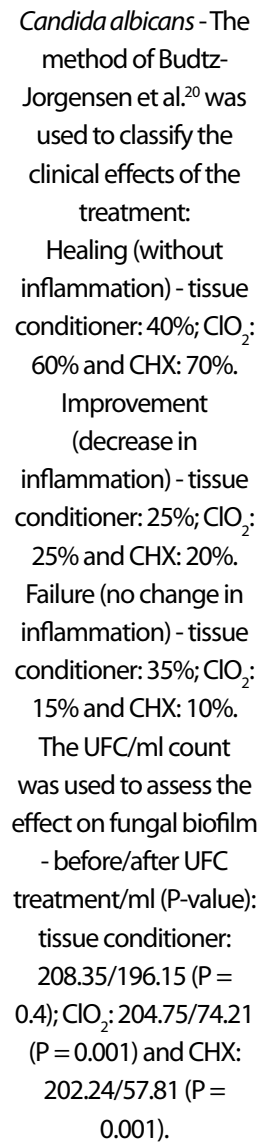 & $\begin{array}{c}\text { Use of both } \\
\text { mouthwashes } \\
\left(\mathrm{ClO}_{2} \text { and } \mathrm{CHX}\right) \\
\text { eliminated } \\
\text { hyphae, } \\
\text { decreased } \\
\text { palatal } \\
\text { inflammation } \\
\text { and } \\
\text { eliminated } \\
\text { Candida } \\
\text { colonization. }\end{array}$ \\
\hline
\end{tabular}


Table 2. Continuation.

\begin{tabular}{|c|c|c|c|c|c|c|c|c|c|}
\hline $\begin{array}{l}\text { Author, } \\
\text { country }\end{array}$ & $\begin{array}{c}\text { Number of } \\
\text { individuals/ } \\
\text { sex/mean age }\end{array}$ & Mouthwash & Concer & ntration & $\begin{array}{l}\text { Quantity } \\
\text { (ml)/ } \\
\text { duration } \\
\text { of } \\
\text { exposure } \\
\text { (s) }\end{array}$ & $\begin{array}{c}\text { Duration } \\
\text { of study } \\
\text { (days) }\end{array}$ & $\begin{array}{l}\text { What was } \\
\text { studied }\end{array}$ & $\begin{array}{l}\text { Microorganism - } \\
\text { Microbiological } \\
\text { count }\end{array}$ & Conclusion \\
\hline $\begin{array}{l}\text { Yadav } \\
\text { et al., }{ }^{8} \\
\text { India }\end{array}$ & $\begin{array}{c}25 / 11 \text { men/ } \\
14 \text { women/ } \\
19.8 \text { years }\end{array}$ & $\begin{array}{c}\text { Stabilized } \mathrm{ClO}_{2} \\
\text { mouth rinse in } \\
\text { aqueous vehicle } \\
\text { Fresh Chlor } \\
\text { (Rowpar Group } \\
\text { Pharmaceuticals, } \\
\text { Bangalore, India). } \\
\text { CHX (0.2\%) } \\
\text { gluconate mouth } \\
\text { rinse in aqueous } \\
\text { vehicle Hexedine } \\
\text { (ICPA, Bangalore, } \\
\text { India). }\end{array}$ & $\begin{array}{l}\text { CHX - } \\
0.20 \%\end{array}$ & $\mathrm{ClO}_{2}-\mathrm{ur}$ & $10 / 60$ & 5 & $\begin{array}{l}\text { To evaluate the } \\
\text { effectiveness of } \\
\text { a mouthwash } \\
\text { containing } \\
\text { stabilized } \\
\mathrm{ClO}_{2} \text { and a } \\
\text { mouthwash } \\
\text { containing CHX } \\
\text { for inhibiting } \\
\text { accumulation } \\
\text { of biofilm on } \\
\text { the tongue and } \\
\text { formation of } \\
\text { dental biofilm. }\end{array}$ & 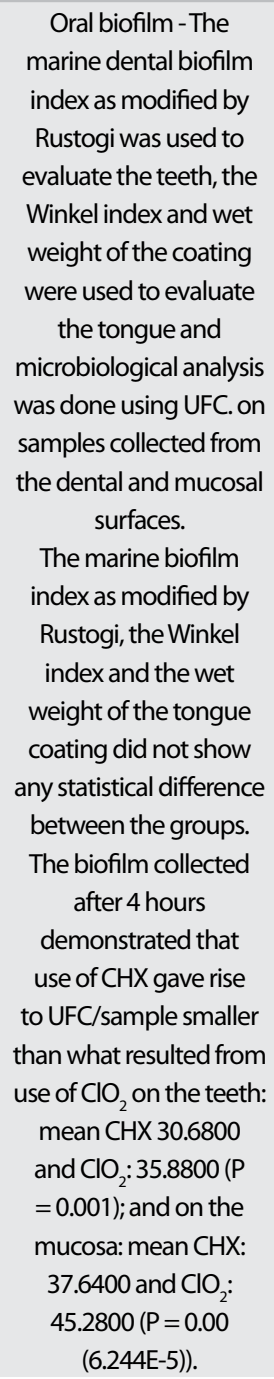 & $\begin{array}{l}\text { The inhibitory } \\
\text { properties } \\
\text { against dental } \\
\text { biofilm, } \\
\text { the rate of } \\
\text { accumulation } \\
\text { of tongue } \\
\text { biofilm and the } \\
\text { antibacterial } \\
\text { properties } \\
\text { of the } \\
\text { mouthwash } \\
\text { with } \mathrm{ClO}_{2} \text { were } \\
\text { comparable } \\
\text { to those of the } \\
\text { mouthwash } \\
\text { with } \mathrm{CHX} \text {. }\end{array}$ \\
\hline $\begin{array}{l}\text { Yeturu } \\
\text { et al.., }{ }^{17} \\
\text { India }\end{array}$ & $\begin{array}{l}85 / 40 \text { men/ } \\
45 \text { women } \\
\text { Aloe vera } \\
\text { group ( } 21.53 \\
\pm 3.41) ; \mathrm{CHX} \\
\text { group ( } 21.72 \\
\pm 4.67) \text { and } \\
\mathrm{ClO}_{2} \text { group } \\
(21.70 \pm 3.01) \text {. }\end{array}$ & $\begin{array}{c}\text { Aloe vera, } \mathrm{ClO}_{2} \\
\text { and } \mathrm{CHX} \text {. }\end{array}$ & $\mathrm{CHX}-\mathrm{ur}$ & $\mathrm{ClO}_{2}-\mathrm{ur}$ & $10 / 60$ & 15 & $\begin{array}{l}\text { To evaluate } \\
\text { the effect of } \\
\text { mouthwashes } \\
\text { containing } \\
\text { Aloe vera, } \mathrm{ClO}_{2} \\
\text { and } \mathrm{CHX} \text { on } \\
\text { biofilm and } \\
\text { gingivitis during } \\
\text { orthodontic } \\
\text { treatment. }\end{array}$ & $\begin{array}{c}\text { Dental biofilm - Dental } \\
\text { biofilm index of Silness } \\
\text { and Loe and gingival } \\
\text { index. } \\
\text { Average percentage } \\
\text { reduction in the dental } \\
\text { biofilm index: Aloe vera } \\
(20.38 \%), \mathrm{CHX}(31.59 \%) \\
\text { and } \mathrm{ClO}_{2}(30.29 \%) \text {, with } \\
\mathrm{P}=0.03 \text {. } \\
\text { Average percentage } \\
\text { reduction in the } \\
\text { gingival index: Aloe } \\
\text { vera (9.88\%), } \mathrm{CHX} \\
(16.30 \%) \text { and } \mathrm{ClO}_{2} \\
(12.22 \%), \text { with } \mathrm{P}=0.04 .\end{array}$ & $\begin{array}{l}\text { Aloe vera and } \\
\mathrm{ClO}_{2} \text { showed } \\
\text { reductions in } \\
\text { dental and } \\
\text { gingival biofilm } \\
\text { rates that were } \\
\text { almost the } \\
\text { same as that } \\
\text { of } \mathrm{CHX} \text { over a } \\
\text { period of } 15 \\
\text { days. Therefore, } \\
\mathrm{ClO} \text { and Aloe } \\
\text { vera may be } \\
\text { suitable and } \\
\text { economical } \\
\text { alternatives to } \\
\text { CHX. }\end{array}$ \\
\hline
\end{tabular}

Continue... 
Table 2. Continuation.

\begin{tabular}{|c|c|c|c|c|c|c|c|c|c|}
\hline $\begin{array}{l}\text { Author, } \\
\text { country }\end{array}$ & $\begin{array}{c}\text { Number of } \\
\text { individuals/ } \\
\text { sex/mean age }\end{array}$ & Mouthwash & Concen & tration & $\begin{array}{l}\text { Quantity } \\
\text { (ml)/ } \\
\text { duration } \\
\text { of } \\
\text { exposure } \\
\text { (s) }\end{array}$ & $\begin{array}{l}\text { Duration } \\
\text { of study } \\
\text { (days) }\end{array}$ & $\begin{array}{l}\text { What was } \\
\text { studied }\end{array}$ & $\begin{array}{l}\text { Microorganism - } \\
\text { Microbiological } \\
\text { count }\end{array}$ & Conclusion \\
\hline $\begin{array}{l}\text { Eunike } \\
\text { et al., }{ }^{16} \\
\text { Indonesia }\end{array}$ & $\begin{array}{l}16 / \text { ur/ 6-11 } \\
\text { years (age } \\
\text { variation) }\end{array}$ & $\begin{array}{c}\text { Mouthwash } \\
\text { containing } \mathrm{ClO}_{2} \\
(0.1 \%) \text { and } \\
\text { mouthwash } \\
\text { containing } \mathrm{CHX} \\
(0.1 \%) .\end{array}$ & $\begin{array}{l}\text { CHX - } \\
0.10 \%\end{array}$ & $\begin{array}{l}\mathrm{ClO}_{2}^{-} \\
0.10 \%\end{array}$ & $10 / 30$ & 7 & $\begin{array}{l}\text { To evaluate the } \\
\text { antibacterial } \\
\text { effects of } \\
\text { mouthwashes } \\
\text { on the bacterial } \\
\text { viability of } \\
\text { Actinomyces sp. } \\
\text { as a black spot } \\
\text { agent. }\end{array}$ & $\begin{array}{l}\text { Actinomyces } s p \text {. } \\
\text { - Feasibility test } \\
\text { with MTT test and } \\
\text { culturing of black } \\
\text { spot samples by } \\
\text { means of visual } \\
\text { inspection and Gram } \\
\text { staining. Average } \\
\text { viability (from } \\
\text { optical density) of } \\
\text { Actinomyces before/ } \\
\text { after using rinses } \\
\text { (P-value) was: } \mathrm{CHX:} \\
0.67 / 0.54(\mathrm{P}=0.01) \\
\text { and } \mathrm{ClO} \mathrm{O}_{2}: 0.73 / 0.40 \\
(\mathrm{P}=0.001) .\end{array}$ & $\begin{array}{c}\text { Mouthwash } \\
\text { containing } \\
0.1 \% \mathrm{ClO}_{2} \\
\text { had greater } \\
\text { antibacterial } \\
\text { effect against } \\
\text { Actinomyces } \\
\text { sp. than rinse } \\
\text { containing } \\
0.1 \% \mathrm{CHX} \text {. }\end{array}$ \\
\hline
\end{tabular}

$\mathrm{CHX}=$ chlorhexidine; $\mathrm{ClO}_{2}=$ chlorine dioxide; $\mathrm{PHMB}=$ polyhexanide; $\mathrm{ur}=$ unreported .

of outcome assessment), ${ }^{8,11-13,15,17}$ given that it was not addressed whether blinding had been applied in order to obtain the results. The other domains of all studies were classified as having low risk of bias. No study was classified as having a high risk of bias in any domain (Figure 2). Therefore, overall, the studies included in this systematic review showed good methodological quality (Figure 3).

\section{DISCUSSION}

Finding a mouthwash that is as effective as CHX and which has fewer adverse effects has been a challenge for researchers. In this systematic review, it was seen that in a study that compared PHMB with CHX, the residual antimicrobial action (substantivity) of $\mathrm{PHMB}^{12,13}$ and its antimicrobial activity were equal to those of $\mathrm{CHX}$. These results make PHMB a viable alternative to $\mathrm{CHX}^{12,13}$ for clinical practice, considering that substantivity is a characteristic that ensures that the product continues to act after its application. All the studies included in this review that compared PHMB with CHX stated the CHX showed substantivity of 12 hours. ${ }^{11-13}$ Previous studies demonstrated that CHX showed substantivity for varying times, ${ }^{21-25}$, viz. up to 7 hours in a 2010 in vivo study, ${ }^{24}$ up to 24 hours in a 1974 study ${ }^{22}$ and up to 12 weeks in a 2009 review. $^{23}$

In biofilm collected from the mouths of individuals to compare $\mathrm{ClO}_{2}$ with $\mathrm{CHX}$, used twice a day for three days, it was found in one study ${ }^{15}$ that there were significant reductions in the total biofilm index in both the test $\left(\mathrm{ClO}_{2}\right)$ and the control
(CHX) groups, and that this reduction was observed in both groups in assessments on different surfaces, i.e. mucous membranes, teeth and upper and lower jaws. In another study, ${ }^{8}$ it was demonstrated that after four days, there was no statistical difference in the degree of destruction of bacteria between the two rinses, ${ }^{8}$ thus also showing that the antimicrobial action of $\mathrm{ClO}_{2}$ was comparable to that of $\mathrm{CHX}$. In an in vitro study ${ }^{26}$ that was carried out to evaluate the action of $\mathrm{ClO}_{2}$ on the dental canal compared with the action of $\mathrm{CHX}$, it was demonstrated that $\mathrm{ClO}_{2}$ was significantly more effective in reducing intracanal bacteria than CHX. In another randomized clinical study ${ }^{27}$ comparing $\mathrm{ClO}_{2}$ with sodium chloride to treat halitosis, $\mathrm{ClO}_{2}$ reduced the amount of tongue coating and Gram-positive and Gram-negative bacteria in the saliva. ${ }^{27}$ In dental black spots caused by Actinomyces sp., $\mathrm{ClO}_{2}$ proved to be statistically more effective in reducing the bacterial viability of Actinomyces sp. than $\mathrm{CHX}$, after seven days of use. ${ }^{16} \mathrm{ClO}_{2}$ is believed to be an effective alternative for use among children, given that this solution is not carcinogenic or allergenic and does not cause any change in taste sensation. Moreover, there are studies that have suggested that it is less toxic to humans than $\mathrm{CHX} .^{16,28}$ Therefore, although CHX is typically considered to be the gold standard, $\mathrm{ClO}_{2}$ is also effective for biofilm control.

When rinses containing $\mathrm{ClO}_{2}$ and $\mathrm{CHX}$ were applied to patients with orthodontic appliances, no statistical differences regarding reduction of the gingival index or total visible biofilm index were 


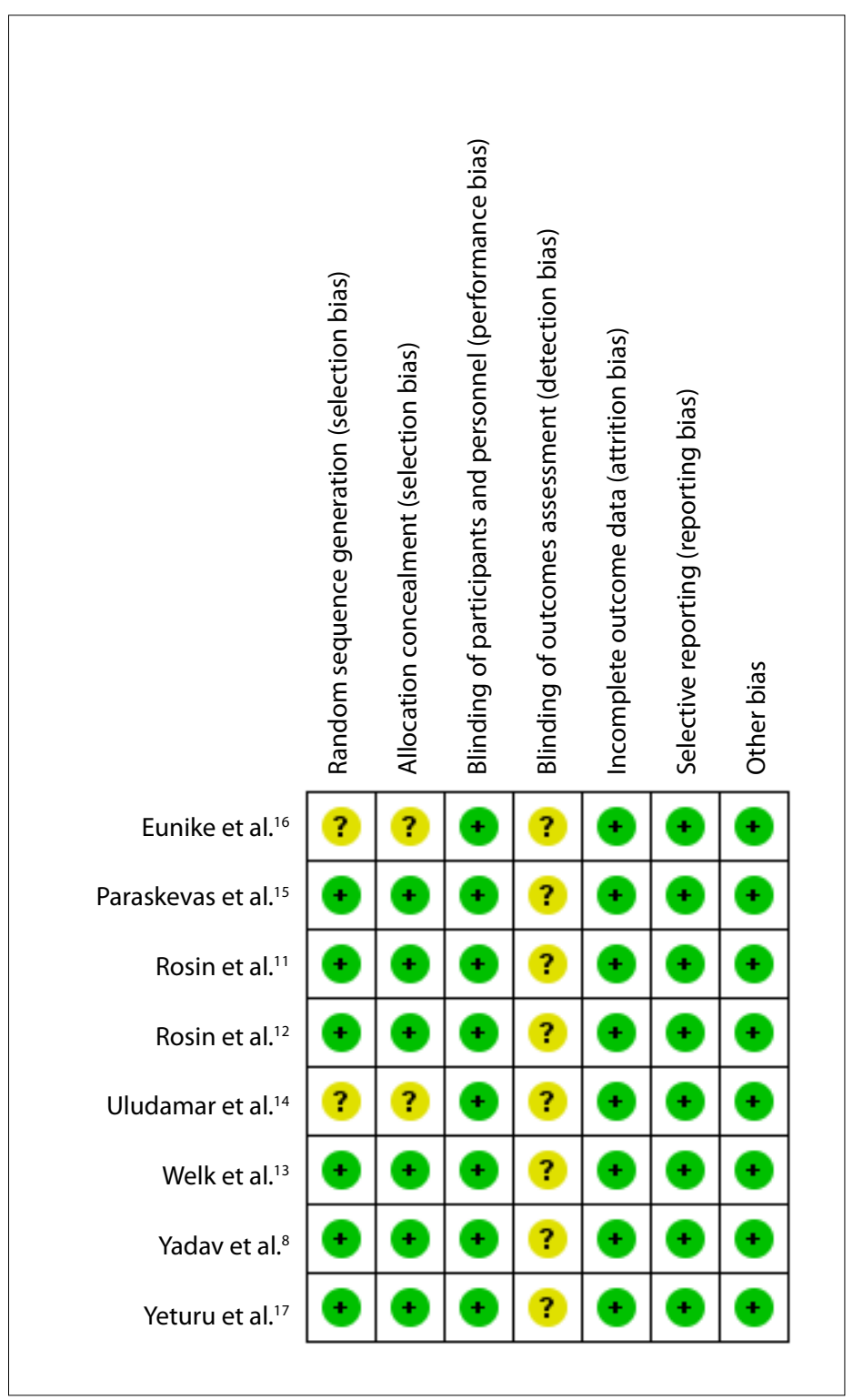

Figure 2. Assessment of the risk of bias in the included studies. observed. ${ }^{17}$ Therefore, the effectiveness of these two solutions for controlling bacterial biofilms seems to be equal.

In a study that evaluated fungal biofilm, ${ }^{14}$ a statistically significant reduction in the number of $C$. albicans hyphae $\left(\mathrm{ClO}_{2}, \mathrm{P}=\right.$ 0.03; and $\mathrm{CHX}, \mathrm{P}>0.01$ ) was observed upon treatment with $\mathrm{ClO}_{2}$ and CHX. Presence of C. albicans in hyphae in the oral mucosa indicated infection by this fungus. ${ }^{29}$ The antifungal effects of these two solutions have already been proven. ${ }^{30,31}$ In addition to reduction of hyphae, $60 \%$ of the patients treated with $\mathrm{ClO}_{2}$ and $70 \%$ of the patients treated with $\mathrm{CHX}$ were found to have achieved a cure for inflammation, ${ }^{14}$ which thus indicates the antifungal effects of $\mathrm{ClO}_{2}$ compared with those of $\mathrm{CHX}$.

\section{Limitations}

There were some limitations to this systematic review, given that in one study the concentrations of mouthwashes used in the experiment $\left(\mathrm{CHX}\right.$ and $\left.\mathrm{ClO}_{2}\right)$ were not reported ${ }^{17}$ and in another the commercial name for the product (Fresh Chlor) was reported but the $\mathrm{ClO}_{2}$ concentration was not reported. ${ }^{8}$ In addition, no study addressed the expected adverse effects. Nor was it reported whether the results from each study were collected in a blinded manner. In this review, no meta-analysis could be performed, given the heterogeneity of purposes observed among the studies included. These conditions also make it difficult to generalize the conclusions, since the synthesis of the results was often based on a limited amount of evidence.

\section{Recommendations}

Because the results from the mouthwashes assessed in this systematic review were equal to or more significant than those from the gold standard $\mathrm{CHX},{ }^{8,11-14,16,17}$ we recommend that future clinical and in vitro studies should be conducted; adverse effects should be considered at the time of evaluation in clinical studies;

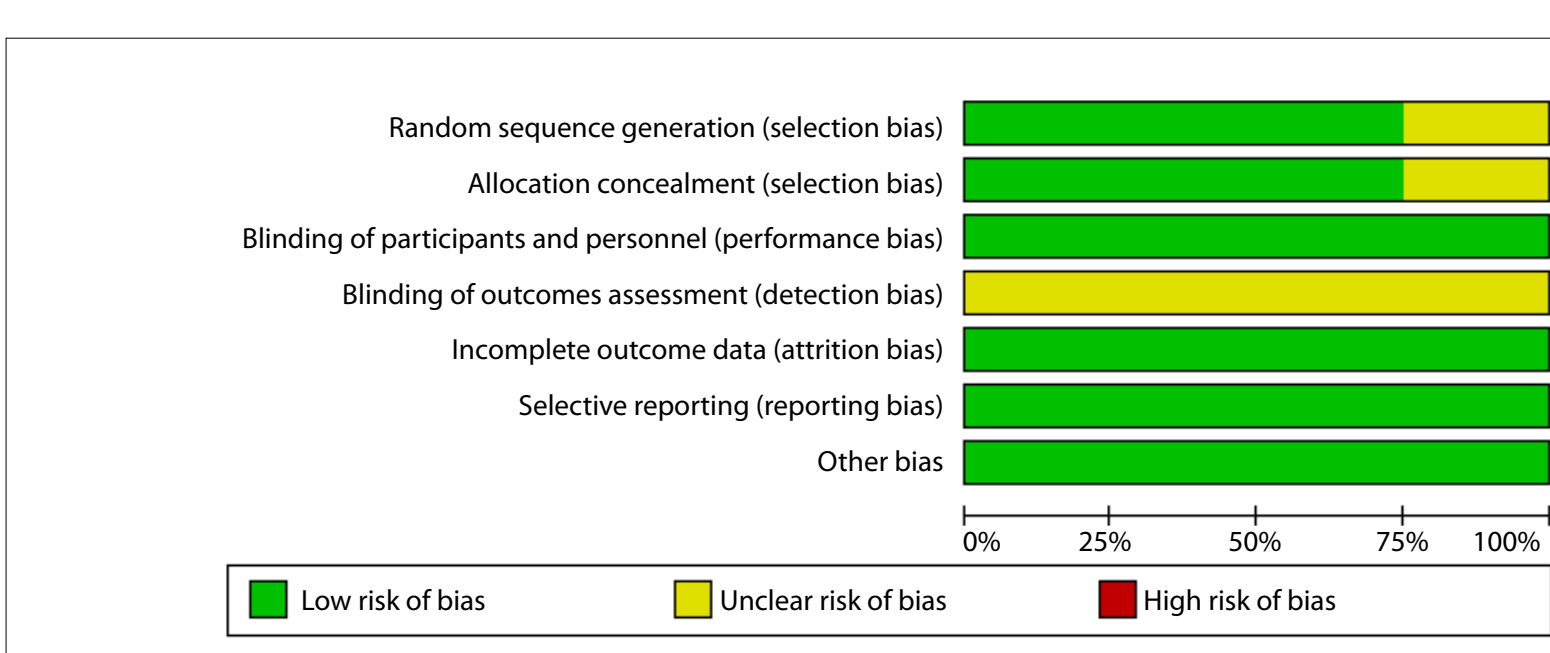

Figure 3. Percentages of risk of bias in studies included. 
products should be specified; and blinding of results should be implemented and demonstrated.

\section{CONCLUSIONS}

Mouthwashes containing $\mathrm{PHMB}$ and $\mathrm{ClO}_{2}$ are viable alternatives to $\mathrm{CHX}$, since studies showed that the antimicrobial effects of PHMB were comparable with those of CHX and that the antimicrobial effects of $\mathrm{ClO}_{2}$ were even greater than those of CHX. These alternative solutions have little or no reported side effects or adverse effects. No study compared both PHMB and $\mathrm{ClO}_{2}$ with $\mathrm{CHX}$.

\section{REFERENCES}

1. Claydon NC. Current concepts in toothbrushing and interdental cleaning. Periodontol 2000. 2008;48:10-22. PMID: 18715352; https:// doi.org/10.1111/j.1600-0757.2008.00273.x.

2. Tufekci E, Casagrande ZA, Lindauer SJ, Fowler CE, Williams KT. Effectiveness of an essential oil mouthrinse in improving oral health in orthodontic patients. Angle Orthod. 2008;78(2):294-8. PMID: 18251611; https://doi.org/10.2319/040607-174.1.

3. Lang N, Brecx M. Chlorhexidine digluconate-an agent for chemical plaque control and prevention of gingival inflammation. Journal of Periodontal Research. 1986;21 Suppl 16:74-89. https://doi. org/10.1111/j.1600-0765.1986.tb01517.x.

4. Mathur S, MathurT, Srivastava R, Khatri R. Chlorhexidine:The gold standard in chemical plaque control. National Journal of Physiology, Pharmacy \& Pharmacology. 2011;1 (2):45-50. Available from: https://www.researchgate. net/publication/265193587_Chlorhexidine_The_Gold_Standard_in_ Chemical_Plaque_Control. Accessed in 2021 (May 26).

5. Eberlein T, Assadian O. Clinical use of polihexanide on acute and chronic wounds for antisepsis and decontamination. Skin Pharmacol Physiol. 2010;23 Suppl:45-51. PMID: 20829662; https://doi. org/10.1159/000318267.

6. Kramer A, Dissemond J, Kim S, et al. Consensus on Wound Antisepsis: Update 2018. Skin Pharmacol Physiol. 2018;31(1):28-58. PMID: 29262416; https://doi.org/10.1159/000481545.

7. Tzanavaras PD, Themelis DG, Kika FS. Review of analytical methods for the determination of chlorine dioxide. Cent Eur J Chem. 2007;5:1-12. https://doi.org/10.2478/s11532-006-0054-9.

8. Yadav SR, Kini VV, Padhye A. Inhibition of Tongue Coat and Dental Plaque Formation by Stabilized Chlorine Dioxide Vs Chlorhexidine Mouthrinse: A Randomized, Triple Blinded Study. J Clin Diagn Res. 2015;9(9):ZC69-74. PMID: 26501017; https://doi.org/10.2478/s11532006-0054-9.

9. Moher D, Liberati A, Tetzlaff J, Altman DG; PRISMA Group. Preferred reporting items for systematic reviews and meta-analyses: the PRISMA statement. PLoS Med. 2009;6(7):e1000097. PMID: 19621072; https:// doi.org/10.1371/journal.pmed.1000097.
10. Carvalho APV, Silva V, Grande AJ. Avaliação do risco de viés de ensaios clínicos randomizados pela ferramenta da colaboração Cochrane. Diagn Tratamento. 2013;18(1):38-44.

11. Rosin M, Welk A, Bernhardt O, et al. Effect of a polyhexamethylene biguanide mouthrinse on bacterial counts and plaque. J Clin Periodontol. 2001;28(12):1121-6. PMID: 11737509; https://doi.org/10.1034/j.1600051x.2001.281206.x.

12. Rosin M, Welk A, Kocher T, et al. The effect of a polyhexamethylene biguanide mouthrinse compared to an essential oil rinse and a chlorhexidine rinse on bacterial counts and 4-day plaque regrowth. J Clin Periodontol. 2002;29(5):392-9. PMID: 12060421; https://doi. org/10.1034/j.1600-051x.2002.290503.x.

13. Welk A, Splieth $\mathrm{CH}$, Schmidt-Martens $\mathrm{G}$, et al. The effect of a polyhexamethylene biguanide mouthrinse compared with a triclosan rinse and a chlorhexidine rinse on bacterial counts and 4-day plaque re-growth. J Clin Periodontol. 2005;32(5):499-505. PMID: 1584226; https://doi.org/10.1111/j.1600-051X.2005.00702.x.

14. Uludamar A, Özyeşil AG, Ozkan YK. Clinical and microbiological efficacy of three different treatment methods in the management of denture stomatitis. Gerodontology. 2011;28(2):104-10.PMID: 20545775; https:// doi.org/10.1111/j.1741-2358.2009.00354.x.

15. Paraskevas $S$, Rosema NA, Versteeg P, Van der Velden $U$, Van der Weijden GA. Chlorine dioxide and chlorhexidine mouthrinses compared in a 3-day plaque accumulation model. J Periodontol. 2008;79(8):1395-400. PMID: 18672988; https://doi.org/10.1902/jop.2008.070630.

16. Eunike MC, Fauziah E, Suharsini M. Antibacterial effects of $0.1 \%$ chlorine dioxide on actinomyces sp. as an agent of black stain. International Journal of Applied Pharmaceutics. 2017;9(Special Issue 2):79-82. https:// doi.org/10.22159/ijap.2017.v9s2.19.

17. Yeturu SK, Acharya S, Urala AS, Pentapati KC. Effect of Aloe vera, chlorine dioxide, and chlorhexidine mouth rinses on plaque and gingivitis: A randomized controlled trial. J Oral Biol Craniofac Res. 2016;6(1):54-8. PMID: 26937371; https://doi.org/10.1016/j. jobcr.2015.08.008

18. Quigley GA, Hein JW. Comparative cleansing efficiency of manual and power brushing. J Am Dent Assoc. 196265:26-9. PMID: 14489483; https://doi.org/10.14219/jada.archive.1962.0184.

19. Turesky S, Gilmore ND, Glickman I. Reduced plaque formation by the chloromethyl analogue of victamine C. J Periodontol. 1970;41 (1):41-3. PMID: 5264376; https://doi.org/10.1902/jop.1970.41.41.41.

20. Budtz-Jörgensen E. The significance of Candida albicans in denture stomatitis. Scand J Dent Res. 1974;82(2):151-90. PMID: 4598186; https:// doi.org/10.1111/j.1600-0722.1974.tb00378.x.

21. Claveau I, Mostefaoui Y, Rouabhia M. Basement membrane protein and matrix metalloproteinase deregulation in engineered human oral mucosa following infection with Candida albicans. Matrix Biol. 2004;23(7):477-86. PMID: 15579314; https://doi.org/10.1016/j. matbio.2004.08.006 
22. Bonesvoll P, Lökken P, Rölla G, Paus PN. Retention of chlorhexidine in the human oral cavity after mouth rinses. Arch Oral Biol. 1974;19(3):209-12. PMID: 4525807; https://doi.org/10.1016/0003-9969(74)90263-5.

23. Mohammadi Z, Abbott PV. The properties and applications of chlorhexidine in endodontics. Int Endod J. 2009;42(4):288-302. PMID: 19220510; https://doi.org/10.1111/j.1365-2591.2008.01540.x.

24. Tomás I, Cousido MC, García-Caballero L, et al. Substantivity of a single chlorhexidine mouthwash on salivary flora: influence of intrinsic and extrinsic factors. J Dent. 2010;38(7):541-6. PMID: 20380865; https://doi. org/10.1016/j.jdent.2010.03.012.

25. Reda B, Hollemeyer K, Trautmann S, Hannig M, Volmer DA. Determination of chlorhexidine retention in different oral sites using matrix-assisted laser desorption/ionization-time of flight mass spectrometry. Arch Oral Biol. 2020;1 10:104623. PMID: 31830639; https://doi.org/10.1016/j. archoralbio.2019.104623.

26. Herczegh A, Gyurkovics M, Ghidan Á, Megyesi M, Lohinai Z. Effect of dentin powder on the antimicrobial properties of hyperpure chlorinedioxide and its comparison to conventional endodontic disinfecting agents. Acta Microbiol Immunol Hung. 2014;61(2):209-20. PMID: 25046882; https://doi.org/10.1556/AMicr.61.2014.2.10.

27. Pham TAV, Nguyen NTX. Efficacy of chlorine dioxide mouthwash in reducing oral malodor: A 2-week randomized, double-blind, crossover study. Clin Exp Dent Res. 201823;4(5):206-15. PMID: 30386642; https:// doi.org/10.1002/cre2.131.

28. Saini R. Efficacy of preprocedural mouth rinse containing chlorine dioxide in reduction of viable bacterial count in dental aerosols during ultrasonic scaling: A double-blind, placebo-controlled clinical trial. Dental Hypotheses. 2015;6(2):65-71. Available from: https://www. dentalhypotheses.com/temp/DentHypotheses6265-5623877_153718. pdf. Accessed in 2021 (May 26).

29. Gow NA, van de Veerdonk FL, Brown AJ, Netea MG. Candida albicans morphogenesis and host defence: discriminating invasion from colonization. Nat Rev Microbiol. 2011;10(2):112-22. PMID: 22158429; https://doi.org/10.1038/nrmicro2711.

30. Barasch A, Safford MM, Dapkute-Marcus I, Fine DH. Efficacy of chlorhexidine gluconate rinse for treatment and prevention of oral candidiasis in HIV-infected children: a pilot study. Oral Surg Oral Med Oral Pathol Oral Radiol Endod. 2004;97(2):204-7. PMID: 14970779; https://doi.org/10.1016/j.tripleo.2003.09.005.

31. Ma JW, Huang BS, Hsu CW, et al. Efficacy and Safety Evaluation of a Chlorine Dioxide Solution. Int J Environ Res Public Health. 2017;14(3):329. PMID: 28327506; https://doi.org/10.3390/ijerph14030329.

Authors' contributions: Santos DSF: conceptualization (lead), data curation (lead), investigation (lead), methodology (lead), project administration (lead), writing-original draft (lead) and writing-review and editing (lead); Peralta-Mamani M: data curation (supporting), formal analysis (supporting), methodology (supporting), software (equal) and writing-review and editing (supporting); Brandão FS: data curation (equal), formal analysis (equal), investigation (equal), resources (equal) and writing-review and editing (supporting); Andrade FB: formal analysis (supporting), methodology (supporting), supervision (supporting) and writing-review \& editing (supporting); Cruvinel T: conceptualization (supporting), formal analysis (supporting), methodology (supporting), supervision (supporting) and writing-review and editing (supporting); and Santos PSS: conceptualization (supporting), data curation (supporting), formal analysis (supporting), methodology (supporting), project administration (lead), supervision (lead), validation (supporting) and writing-review and editing (supporting). All authors actively contributed to discussion of the results from the study, and reviewed and approved the final version to be released

Sources of funding: Coordenação de Aperfeiçoamento de Pessoal de Nível Superior - Brasil (CAPES) - finance code 001

Conflict of interest: None

Date of first submission: December 21, 2020

Last received: March 17, 2021

Accepted: May 18, 2021

\section{Address for correspondence:}

Paulo Sérgio da Silva Santos

Departamento de Cirurgia, Estomatologia, Radiologia e Patologia, Faculdade de Odontologia de Bauru (FOB), Universidade de São Paulo (USP)

Al. Doutor Octávio Pinheiro Brisolla, 9-75

Bauru (SP) - Brasil

CEP 17012-901

Tel. (+55 14) 3226-6113

E-mail:paulosss@fob.usp.br 